\title{
Behçet's Disease as a Model of Venous Thrombosis
}

\author{
Micaela La Regina ${ }^{1,2, *}$, Armen Yuri Gasparyan ${ }^{3}$, Francesco Orlandini ${ }^{2}$ and Domenico Prisco ${ }^{4}$ \\ ${ }^{I}$ Department of Internal Medicine, Periodic Fevers Research Centre, Catholic University, Rome, Italy \\ ${ }^{2}$ Department of Internal Medicine, Ligurian East Hospital, La Spezia, Italy \\ ${ }^{3}$ Dudley Group of Hospitals NHS Trust, Dudley, West Midlands, UK \\ ${ }^{4}$ Department of Medical and Surgical Critical Care, University of Florence, Florence, Italy
}

\begin{abstract}
Behçet's disease (BD) is a chronic inflammatory disease of unknown aetiology characterized by recurrent oral, genital aphthous ulcerations, uveitis, skin lesions and other multisystem affections associated with vasculitis. Different types of vessels, predominantly veins, can be affected in BD. The frequency of vascular lesions in BD, such as superficial and deep venous thromboses, arterial aneurysms and occlusions, ranges between 7-29\%.

In this review, various factors of thrombogenesis in BD, particularly pro- and antithrombotic endothelial and nonendothelial factors, factors of coagulation, platelet activation and rheological changes are presented and discussed from positions of Virchow's triad of venous thrombosis.

Despite advances in understanding of thrombogenesis in BD, still many issues of diagnosis and targeted preventive and therapeutic measures remain unresolved. Further studies are needed to clarify the pathobiology of BD-related thrombosis and to provide the clinicians with recommendations over the utility, safety and effectiveness of the antithrombotic therapy in BD.
\end{abstract}

Keywords: Behçet's disease, Thrombosis, Venous thrombosis, Arterial thrombosis, Vascular diseases, Virchow’s triad.

\section{INTRODUCTION}

Behçet's disease (BD) is a chronic systemic disorder of unknown etiology characterized by recurrent oral and/or genital aphthous ulcerations, uveitis and skin lesions. Clinical presentation of this disorder is multifaceted and includes articular, central nervous system, gastrointestinal, renal, urogenital, pulmonary and cardiovascular manifestations, all of which are associated with systemic vasculitis, a pivotal pathophysiological feature of BD [1-4]. Recently, BD was classified into a group of auto-inflammatory disorders, sharing some common innate immune and genetic mechanisms of dysregulation of inflammation [5,6], which can cause endothelial damage, activation of coagulation and thrombosis, and underlie vascular morbidity and mortality $[7,8]$.

Linked to the predisposing genetic and, possibly, environmental factors, cardiovascular pathology in BD represents a unique spectrum of inflammatory, thrombotic and aneurysmatic disorders. Importantly, vessels of any size and type can be affected, with venous pathology being recognized as a hallmark of the disease $[9,10]$. The frequency of vascular involvement in BD (superficial and deep venous thromboses, arterial aneurysms, occlusions) ranges between $7-29 \%$ [9]. In a large observational study, it was shown that

*Address correspondence to this author at the Department of Internal Medicine, Periodic Fevers Research Centre, Catholic University, Largo F.Vito 1, 00168 Rome, Italy; Tel: 0039338 2393805; Fax: 0039 (0)187 533483; E-mail: micaela.laregina@rm.unicatt.it about one quarter of patients with BD present with vascular involvement, of whom, only $12 \%$ with arterial pathology [11]. Though venous thrombosis of the lower extremities is thought to be the most frequent type of vascular pathology in $\mathrm{BD}$, with the advent of new diagnostic techniques, such as magnetic resonance imaging, thromboses of other venous sites have been identified and reported in a series of recent observations (e.g. in superior and inferior vena cava, coronary, portal, renal, pulmonary veins) [12-15]. Aneurysmatic, pseudoaneurysmatic and thrombotic affections of large- and medium-size arteries, right-sided intracardiac thrombotic masses have also been reported, indicating complexity, life-threatening nature of thrombocoagulopathy in $\mathrm{BD}$ and importance of complex primary and secondary prevention [16-18].

In clinical practice, especially in the debut of $\mathrm{BD}$, diagnosis and treatment of thrombosis is a challenge, requiring careful consideration of multiple thrombophilic factors and limited therapeutic options [19]. Based on experts' opinion, tight immunosuppressive therapy is, nowadays, a prerequisite of anti-thrombotic measures in BD. Anti-platelet therapy with aspirin is used in the most cases without major adverse effects. Experts, however, expressed caution over the use of anticoagulants, which can cause major bleedings (e.g. massive pulmonary haemorrhage from affected vessels) [1]

BD with its well-known tendency towards thrombosis and vasculopathy can serve as a clinical model of inflammation-related thrombosis. In this regard, investigation of 
factors and mechanisms involved in thrombosis in BD may have far-reaching implications for the whole group of auto-inflammatory disorders and cardiovascular prevention in the general population [20].

The aim of this review is to present some factors involved in thrombocoagulation in $\mathrm{BD}$.

\section{THROMBOGENESIS IN BD}

Thrombogenesis in $\mathrm{BD}$ can be best viewed through the concept of Virchow's triad of venous thrombosis. Based on this concept, thrombus formation requires a combination of at least 2 out of 3 pathological components (abnormal blood flow, abnormal vessel wall, abnormal blood constituents) [21]. From this standpoint, BD can be viewed as a clinical model of venous thromboembolism. Abnormal blood flow due to the disturbances in microcirculation, increased blood viscosity are often coexisting with endothelial dysfunction, arterial aneurysms, venous varices, and numerous proinflammatory and prothrombotic changes of blood constituents. Direct damage of the endothelium, from one side, and vasculitis of vasa vasorum (more correctly, perivasculitis), from the other, cause destruction of vascular elastic structures and lead to aneurysm formation, further disrupt blood flow. Relapses of phlebitis with venous thrombosis eventually lead to post-thrombophlebitic syndrome with sustaining venous blood flow abnormalities.

\section{Endothelial Factors}

It is well known that in physiological conditions pro- and anti-coagulant endothelial activities are well balanced. Endothelial cell injury activates coagulation cascade by exposing subendothelial collagen, by releasing pro-coagulant endothelial agents, such as tissue factor (TF), von Willebrand factor (vWF), E-selectin, P-selectin and other adhesion molecules, thromboxane A2 (TxA2), the type-1 inhibitor of plasminogen activators (PAI-1), platelet activator factor (PAF), and by reducing activity of anti-thrombotics, such as prostacyclin (PGI2), nitric oxide (NO), thrombomodulin, tissue plasminogen activator (t-PA), urokinase-type plasminogen activator (u-PA), tissue factor pathway inhibitor (TFPI).

In a series of case-control studies, elevated levels of circulating vWF, a large multimeric glycoprotein, that binds and protects Factor VIII from degradation, and facilitates platelet adhesion, were found in patients with BD. Levels of vWF were especially high in those with thrombosis, who were also found to have highest levels of t-PA, a serineprotease responsible for clot destruction. All these shifts were triggered by endothelial damage [22-27].

Reduced levels of thrombomodulin, an endothelial membrane protein and co-factor of anticoagulant protein $\mathrm{C}$, were shown to be associated to an increased risk of thrombosis in BD [28, 29].

Tissue factor pathway inhibitor (TFPI) is another endothelial protein, which reversibly inhibit Factor $\mathrm{Xa}(\mathrm{Xa})$ and thrombin (Factor IIa). Depletion of endothelial TFPI in BD was found in one study [30], while another study reported its elevation [31]. This discrepancy is, probably, due to laboratory measurements undertaken at different stages of disease activity.
An enhanced expression of E-selectin, adhesion molecule produced by endotheliocytes, was found in patients with BD with endothelial alterations at different sites (e.g. inflamed conjunctiva, erythema nodosum), and was associated with disease activity [32-37]. Immunosuppressive therapy was shown to reduce E-selectin levels in $\mathrm{BD}[37,38]$. It was also found that overexpression of E-selectin in BD is strongly and positively correlated with acute-phase reactants, such as Creactive protein (CRP) [39].

Diminished production of nitric oxide (NO) by endothelial cells, known to reflect endothelial microvascular function, was found in patients with BD in some [40-43], but not all studies [44-46]. Production of NO and its release into circulation can be impaired because of ongoing inflammation and oxidative stress, a crucial pathophysiological component of active BD $[47,48]$. Reduced bioavailability of NO may predispose to enhanced platelet aggregation eventually leading to thrombotic complications [47]. Genetic factors, namely single nucleotide polymorphisms of endothelial NO synthase (eNOS), can underlie endothelial dysfunction in BD. In fact, Glu298Asp polymorphism in exon 7 of eNOS associated to endothelial dysfunction, may explain the susceptibility of certain ethnic background to BD [49-52].

Another product of endothelial cells, endothelin-1, is a potent vasoconstrictor which antagonizes the effects of NO. Its involvement in vascular inflammation deteriorates vascular functions and leads to thrombosis. In patients with BD, high levels of this protein were found in association with disease activity and retinal vein occlusion [53-56].

Vascular endothelial growth factor (VEGF) is a marker of angiogenesis and endothelial dysfunction, which is produced by endothelial and some other cells in response to ischemia [57, 58]. In several small case-control studies, over-expression of VEGF was found in patients with BD [59-64], mainly during the active stage of the disease, in the case of ocular involvement and acute thrombosis. Attempts were made to associate VEGF gene polymorphisms with the development of BD and retinal vasculitis in Italian [65] and Korean [66] cohorts of patients, with conflicting results, probably, due to the ethnic differences.

TFPI is a Kunitz-type proteinase inhibitor, which is produced by endotheliocytes and released into the circulation upon stimulation by heparin. Its main function is to antagonize the effects of factor VIIa, factor $\mathrm{Xa}$ and thrombin. In one study, an increase of TFPI was found in BD patients, reflecting defensive activation of the system of antithrombosis [67]. In another study, its baseline levels in BD patients were normal, but the degree of stimulated by heparin release was lower compared with SLE patients and healthy controls [30].

\section{Procoagulant Factors}

Leiden point mutation in the gene of Factor $\mathrm{V}$ (Arg506Glu), causing resistance of Factor $\mathrm{V}$ to proteolysis by activated protein $\mathrm{C}$, and the prothrombin gene G20210A mutation, leading to elevation of prothrombin levels, are common genetic factors associated with venous thrombosis in the general population [68]. Given the crucial role of these mutations in venous thrombogenesis, it was initially thought that these factors are culprits of prothrombotic state in BD. 
However, in a multiple series of studies on the prevalence of these mutations among BD patients and possible association with disease activity, ocular involvement, thrombosis, homocysteinemia, CRP and other mutations related to coagulation, the obtained results were controversial [69-78]. For example, the prevalence of Factor $\mathrm{V}$ Leiden mutation was shown to vary among patients with venous thrombosis between 0 and $37.5 \%$ [69]. No association was found between Factor V Leiden, the prothrombin gene mutation, methylenetetrahydrofolate reductase (MTHFR) C677T polymorphism, from one side, and CRP, homocysteine, factor VIII, from another [70]. In a recent meta-analysis of studies on Factor V Leiden, the prothrombin gene, MTHFR mutations and venous thrombosis in $\mathrm{BD}$, the prothrombin gene mutation was found to be strongly associated with thrombosis (also after excluding results of Turkish studies) [79].

High levels of factor VIII, which is intimately involved in the coagulation cascade, were shown to be strongly associated with the risk of thrombosis in population-based studies $[80,81]$. Importantly, factor VIII was independently associated with recurrent venous thromboembolism in non-BD subjects [82]. In cohorts of BD patients, the results were not equivocal $[26,70,82-84]$, with the majority of studies, indicating elevation of plasma levels of this factor, alone or in association with vWF, which stabilizes factor VIII and, thus, enhances thrombogenesis [85].

Factor IX, another factor of coagulation, was found to be elevated in one case of a BD patient presented with intracardiac thrombus and pulmonary aneurysm [86].

Lipoprotein (a) is a low density lipoprotein, containing apolipoprotein B and apolipoprotein (a). Lipoprotein (a) exerts both atherogenic and anti-fibrinolytic effects [87-89]. Similar to plasminogen, lipoprotein (a) binds to fibrin [90, 91]. Elevated levels of lipoprotein (a) in BD were found in the most [92-95] but not all case-control studies [96]. Based on the obtained data [92-95], it is possible that this lipoprotein plays active role in vascular involvement and thrombosis in $\mathrm{BD}$ by stimulating the release of plasminogen activator inhibitor-1 (PAI-1) from endotheliocytes, resulting in hypofibrinolysis.

Antiphospholipid antibodies promote coagulation by acting against membranes phospholipids, by binding beta-2glycoprotein I, prothrombin, annexin V, activated protein $\mathrm{C}$, protein $\mathrm{S}$ and cross-reacting with thrombomodulin [97-100]. Pro-coagulant activity of these antibodies was associated with arterial and venous thromboembolism [97].

Many antiphospholipid antibodies were tested in BD [101-107], and except for a few small initial studies [101, 102], where elevated levels of anticardiolipin antibodies were associated with retinal and cerebrovascular pathology in $\mathrm{BD}$, the majority of the studies failed to report elevation of antiphospholipid antibodies and association with thrombosis, suggesting that, unlike systemic lupus erythematosus (SLE) and primary antiphospholipid syndrome, in this autoinflammatory disorder the role of autoantibodies is insignificant.

\section{Anticoagulant Factors}

Congenital deficiencies of anticoagulants, such as protein C, S (inhibitor of activated factor $\mathrm{V}$ and factor VIII) and antithrombin (inactivator of factor II and other coagulation factors), predispose to thrombophilia in the general population. In BD, however, their involvement in thrombotic complications is insignificant [108-110].

Protein $\mathrm{Z}$ is another anticoagulant, a vitamin $\mathrm{K}$ dependent protein acting as a co-factor in the pathway of activated factor $\mathrm{X}(\mathrm{FXa})$ inhibition. In one small case-control study, it was found to be decreased in patients with BD without vascular involvement [111].

\section{Fibrinolytic Factors}

Decreased fibrinolysis has long been recognized as a key factor implicated in coagulopathy in BD [26, 112]. Many case-control studies on t-PA in BD yielded conflicting results, indicating its decreased [93], increased [28] or unchanged activity $[24,73]$. The majority of studies on PAI-1, however, found increased levels of this inhibitor of plasminogen activation in patients with BD with or without established thrombosis $[93,113]$. Another inhibitor of fibrinolysis, thrombin activatable fibrinolysis inhibitor (TAFI), which is associated with venous thromboembolism in the general population, was assayed in patients with $\mathrm{BD}$ and found to be increased in one study [113]. PAI-1 and TAFI associated genetic polymorphisms were also tested in this study however there was not any association with BD.

\section{Markers of Platelet Activation}

Few studies investigated platelet function in BD [114118 ] and found enhanced in vitro platelet aggregation in response to adenosine diphosphate (ADP) [114-116], impaired sensitivity of platelets to prostacyclin [23], overexpression of platelet bound P-selectin [117]. Patients with thrombosis demonstrated sustained overexpression of P-selectin and higher levels of platelet microparticles, and circulating microaggregates [118], which is suggestive of a role of platelets in thrombogenesis in BD. Importantly, in one small study, it also was found that the prevalence of 807TT genotype and $807 \mathrm{~T}$ allele of the platelet glycoprotein Ia C807T/G873 A gene polymorphism is higher in patients with $\mathrm{BD}$ compared with healthy controls, which may suggest genetically predetermined platelet hyperfunction in BD [119]. It should be, however, noted that these data were not uniformly confirmed, pending further more robust investigations.

\section{Others Factors}

It was suggested that disturbances in the blood rheology may also play a role in thrombosis due to BD. High plasma and blood viscosity, and enhanced erythrocyte aggregation, which are measures of impaired blood rheology, were noted in patients with $\mathrm{BD}[120,121]$. However, "blood flow abnormalities" in BD still need to be tested in patients with and without thrombosis, case-control and longitudinal studies.

\section{CONCLUSIONS}

Despite advances in understanding of diverse mechanisms of thrombogenesis in $\mathrm{BD}$, there are still many unresolved issues of diagnosis and targeted preventive and therapeutic measures.

To date, the majority of studies on thrombosis in BD examined this issue fragmentally, concentrating on separate features without appreciating coexistence of diverse compo- 
Table 1. Factors Involved in Thrombogenesis in BD and Possible Therapeutic Measures

\begin{tabular}{|c|c|c|}
\hline Blood flow abnormalities & $\begin{array}{c}\text { Enhanced erythrocyte aggregation, increased fibrinogen, high blood viscosity } \\
\text { Impaired microcirculation } \\
\text { Turbulent blood flow at sites of venous varices and arterial aneurysms } \\
\text { Arterial and venous occlusion }\end{array}$ & $\begin{array}{l}\text { Immunosuppressive drugs } \\
\text { Aspirin } \\
\text { Heparin (?) } \\
\text { Warfarin (?) }\end{array}$ \\
\hline Abnormal blood constituents & $\begin{array}{c}\text { Endothelial factors (increase/decrease of vWF, t-PA, thrombomodulin, } \\
\text { NO, VEGF, endothelin-1) } \\
\text { Procoagulant factors [factor V Leiden and prothrombin mutations, } \\
\text { hyperhomocystenemia, factors VIII, IX, lipoprotein (a)] } \\
\text { Factors of fibrinolysis increase/decrease of TAFI, PAI-1, t-PA } \\
\text { Anticoagulant factors (protein C, S, Z, TFPI, antithrombin) } \\
\text { Platelets hyperactivity }\end{array}$ & $\begin{array}{l}\text { Immunosuppressive drugs } \\
\text { Heparin (?) } \\
\text { Warfarin (?) } \\
\text { Aspirin }\end{array}$ \\
\hline
\end{tabular}

nents of thrombosis. Accumulated evidence derived predominantly from multiple case-control studies suggests that all components of Virchow's triad of thrombosis, namely abnormal blood flow, abnormal vessel wall and abnormal blood constituents, are present in BD (Table 1). The time has come to investigate all these components together in large prospective cohorts of patients. It would be also useful to launch a multinational study, investigating implications of diverse environmental, genetic and acquired risk factors of thrombosis in different ethnic inceptive cohorts of patients.

The prevailing expert's opinion on the treatment of thrombosis in BD still supports immunosuppressive agents and is cautious over the use of anticoagulants, such as warfarin and heparin [122]. Uncertainties surround the issue of thrombolysis, anticoagulation and coronary angioplasty in acute coronary syndromes in BD [123]. Further studies, aimed to compare different antithrombotics and/or immunosuppressive agents on large samples, are warranted to provide the clinician with recommendations over the safety and effectiveness of antithrombotic therapy in BD.

\section{REFERENCES}

[1] Hatemi G, Silman A, Bang D, et al. EULAR recommendations for the management of Behçet disease. Ann Rheum Dis 2008; 67: 1656-62.

[2] Yurdakul S, Yazici H. Behçet's syndrome. Best Pract Res Clin Rheumatol 2008; 22: 793-809.

[3] Calamia KT, Kaklamanis PG. Behçet's disease: recent advances in early diagnosis and effective treatment. Curr Rheumatol Rep 2008; 10: 349-55.

[4] Kontogiannis V, Powell RJ. Behçet's disease. Postgrad Med J 2000; 76: 629-37.

[5] Gül A. Behçet's disease as an autoinflammatory disorder. Curr Drug Targets Inflamm Allergy 2005; 4: 81-3.

[6] Galeazzi M, Gasbarrini G, Ghirardello A, et al. Autoinflammatory syndromes. Clin Exp Rheumatol 2006; 24(1 Suppl 40): S79-85.

[7] Yazici H, Fresko I, Yurdakul S. Behçet's syndrome: disease manifestations, management, and advances in treatment. Nat Clin Pract Rheumatol 2007; 3: 148-55.
[8] Calamia KT, Schirmer M, Melikoglu M. Major vessel involvement in Behçet disease. Curr Opin Rheumatol 2005; 17: 1-8.

[9] Kuzu MA, Ozaslan C, Köksoy C, Gürler A, Tüzüner A. Vascular involvement in Behçet's disease: 8-year audit. World J Surg 1994; 18: 948-53.

[10] Atzeni F, Sarzi-Puttini P, Doria A, Boiardi L, Pipitone N, Salvarani C. Behçet's disease and cardiovascular involvement. Lupus 2005; 14: 723-6.

[11] Koç Y, Güllü I, Akpek G, et al. Vascular involvement in Behçet's disease. J Rheumatol 1992; 19: 402-10.

[12] Radke PW, Schwarz ER, Groesdonk H, Graf J, Janssens U. Thrombosis in Behcet's disease: report of a case followed by a systematic review using the methodology of evidence-based medicine. J Thromb Thrombolysis 2001; 11: 137-41.

[13] Saadoun D, Wechsler B, Resche-Rigon M, et al. Cerebral venous thrombosis in Behçet's disease. Arthritis Rheum 2009; 61: 51826.

[14] Korkmaz C, Kasifoglu T, Kebapçi M. Budd-Chiari syndrome in the course of Behcet's disease: clinical and laboratory analysis of four cases. Joint Bone Spine 2007; 74: 245-8.

[15] Malik GH, Sirwal IA, Pandit KA. Behcet's syndrome associated with minimal change glomerulonephritis and renal vein thrombosis. Nephron 1989; 52: 87-9.

[16] Karatepe O, Ziyade S, Ugurlucan M, Gasparyan AY. eComment: treatment of pulmonary artery aneurysm in Behcet's disease - few things can make big differences. Interact Cardiovasc Thorac Surg 2009; 8: 392.

[17] Marzban M, Mandegar MH, Karimi A, et al. Cardiac and great vessel involvement in "Behcet's disease". J Card Surg 2008; 23: 765-8.

[18] Kakafika AI, Mikhailidis DP. Smoking and aortic diseases. Circ J 2007; 71: 1173-80.

[19] Benedetti R, Brignone A, Incerti VL, Orlandini F. An atypical vascular case of Behçet's disease and consequent treatment. Intern Emerg Med 2009; 4: 179-80.

[20] Gasparyan AY, Ugurlucan M. The emerging issue of cardiovascular involvement in familial Mediterranean fever. Arch Med Sci 2008; 4: 465-7.

[21] Lippi G, Franchini M. Pathogenesis of venous thromboembolism: when the cup runneth over. Semin Thromb Hemost 2008; 34: 74761.

[22] Koşar A, Haznedaroğlu IC, Büyükaşik Y, Kirazli S, Dündar SV. Activated protein $\mathrm{C}$ resistance in Behçet's disease. Rheumatol Int 1998; 17: 249-50. 
[23] Wilson AP, Efthimiou J, Betteridge DJ. Decreased prostacyclin sensitivity of platelets in patients with Behçet's syndrome. Eur J Clin Invest 1988; 18: 410-4.

[24] Aitchison R, Chu P, Cater DR, Harris RJ, Powell RJ. Defective fibrinolysis in Behçet's syndrome: significance and possible mechanisms. Ann Rheum Dis 1989; 48: 590-3.

[25] Lê Thi Huong D, Wechsler B, Papo T, et al. Arterial lesions in Behçet's disease. A study in 25 patients. J Rheumatol 1995; 22: 2103-13.

[26] Hampton KK, Chamberlain MA, Menon DK, Davies JA. Coagulation and fibrinolytic activity in Behçet's disease. Thromb Haemost 1991; 66: 292-4

[27] Ozoran K, Dügün N, Gürler A, Tutkak H, Tokgöz G. Plasma von Willebrand factor, tissue plasminogen activator, plasminogen activator inhibitor, and antithrombin III levels in Behçet's disease. Scand J Rheumatol 1995; 24: 376-82.

[28] Demirer S, Sengül N, Yerdel MA, et al. Haemostasis in patients with Behçet's disease. Eur J Vasc Endovasc Surg 2000; 19: 570-4.

[29] Espinosa G, Font J, Tassies D, et al. Behcet's disease, encothelium and thrombosis [abstract]. Arthritis Rheumatism 2000; 43(suppl): S124.

[30] Ertenli I, Kiraz S, Celik IC, et al. Changes in the concentration and distribution of tissue factor pathway inhibitor in Behçet's disease and systemic lupus erythematosus: effect on the prethrombotic state. Ann Rheum Dis 2001; 60: 1149-51.

[31] Akarsu M, Demirkan F, Ozsan GH, et al. Increased levels of tissue factor pathway inhibitor may reflect disease activity and play a role in thrombotic tendency in Behçet's disease. Am J Hematol 2001; 68: $225-30$.

[32] Triolo G, Accardo-Palumbo A, Triolo G, Carbone MC, Ferrante A, Giardina E. Enhancement of endothelial cell E-selectin expression by sera from patients with active Behçet's disease: moderate correlation with anti-endothelial cell antibodies and serum myeloperoxidase levels. Clin Immunol 1999; 91: 330-7.

[33] Lee KH, Chung HS, Bang D, Lee S. Behçet's disease sera containing antiendothelial cell antibodies promote adhesion of $\mathrm{T}$ lymphocytes to cultured human dermal microvascular endothelial cells. Yonsei Med J 1999; 40: 152-8

[34] Tugal-Tutkun I, Urgancioglu M, Foster CS. Immunopathologic study of the conjunctiva in patients with behçet disease. Ophthalmology 1995; 102: 1660-8.

[35] Sentürk T, Aydintuğ O, Kuzu I, et al. Adhesion molecule expression in erythema nodosum-like lesions in Behçet's disease. A histopathological and immunohistochemical study. Rheumatol Int 1998; 18: $51-7$.

[36] Haznedaroglu E, Karaaslan Y, Büyükaşik Y, et al. Selectin adhesion molecules in Behçet's disease. Ann Rheum Dis 2000; 59: 61-3

[37] Kosar A, Haznedaroglu S, Karaaslan Y, et al. Effects of interferonalpha2a treatment on serum levels of tumor necrosis factor-alpha, tumor necrosis factor-alpha2 receptor, interleukin-2, interleukin-2 receptor, and E-selectin in Behçet's disease. Rheumatol Int 1999; 19: $11-4$

[38] Ateş A, Tiryaki OA, Olmez U, Tutkak H. Serum-soluble selectin levels in patients with Behçet's disease. Clin Rheumatol 2007; 26: 411-7.

[39] Sari RA, Kiziltunç A, Taysi S, Akdemir S, Gündoğdu M. Levels of soluble E-selectin in patients with active Behcet's disease. Clin Rheumatol 2005; 24: 55-9.

[40] Orem A, Vanizor B, Cimşit G, Kiran E, Değer O, Malkoç M. Decreased nitric oxide production in patients with Behçet's disease. Dermatology 1999; 198: 33-6.

[41] Karasneh JA, Hajeer AH, Silman A, Worthington J, Ollier WE, Gul A. Polymorphisms in the endothelial nitric oxide synthase gene are associated with Behçet's disease. Rheumatology (Oxford) 2005; 44: 614-7.

[42] Sahin M, Arslan C, Naziroglu M, et al. Asymmetric dimethylarginine and nitric oxide levels as signs of endothelial dysfunction in Behcet's disease. Ann Clin Lab Sci 2006; 36: 449-54.

[43] Buldanlioglu S, Turkmen S, Ayabakan HB, et al. Nitric oxide, lipid peroxidation and antioxidant defence system in patients with active or inactive Behçet's disease. Br J Dermatol 2005; 153: 526-30.

[44] Evereklioglu C, Turkoz Y, Er H, Inaloz HS, Ozbek E, Cekmen M. Increased nitric oxide production in patients with Behçet's disease: is it a new activity marker? J Am Acad Dermatol 2002; 46: 50-4.

[45] Akdeniz N, Esrefoglu M, Keleş MS, Karakuzu A, Atasoy M. Serum interleukin-2, interleukin-6, tumour necrosis factor-alpha and nitric oxide levels in patients with Behcet's disease. Ann Acad Med Singapore 2004; 33: 596-9.

[46] Sancak B, Onder M, Oztas MO, Bukan N, Gürer MA. Nitric oxide levels in Behçet's disease. J Eur Acad Dermatol Venereol 2003; 17 : 7-9.

[47] Yapişlar H, Aydogan S, Borlu M, Ascioglu O. Decreased nitric oxide and increased platelet aggregation levels in patients with Behçet's disease. Thromb Res 2007; 119: 461-5.

[48] Karasneh JA, Hajeer AH, Silman A, Worthington J, Ollier WE, Gul A. Polymorphisms in the endothelial nitric oxide synthase gene are associated with Behçet's disease. Rheumatology (Oxford) 2005; 44: 614-7.

[49] Harzallah O, Kerkeni A, Baati T, Mahjoub S. Oxidative stress: correlation with Behçet's disease duration, activity and severity. Eur J Intern Med 2008; 19: 541-7.

[50] Kim JU, Chang HK, Lee SS, et al. Endothelial nitric oxide synthase gene polymorphisms in Behçet's disease and rheumatic diseases with vasculitis. Ann Rheum Dis 2003; 62: 1083-7.

[51] Ben Dhifallah I, Houman H, Khanfir M, Hamzaoui K. Endothelial nitric oxide synthase gene polymorphism is associated with Behçet's disease in Tunisian population. Hum Immunol 2008; 69: 661-5.

[52] Nakao K, Isashiki Y, Sonoda S, Uchino E, Shimonagano Y, Sakamoto T. Nitric oxide synthase and superoxide dismutase gene polymorphisms in Behçet disease. Arch Ophthalmol 2007; 125: 24651.

[53] Ural AU, Yalcin A, Beyan C, Isimer A, Bayhan H. Plasma endothelin-1 concentrations in patients with Behçet's disease. Scand J Rheumatol 1994; 23: 322-5.

[54] Ural AU. Increased plasma endothelin-1 levels in active Behçet's disease. Clin Rheumatol 1997; 16: 640.

[55] Iannaccone A, Letizia C, Pazzaglia S, Vingolo EM, Clemente G, Pannarale MR. Plasma endothelin-1 concentrations in patients with retinal vein occlusions. Br J Ophthalmol 1998; 82: 498-503.

[56] Er H, Evereklioglu C, Cumurcu T, et al. Serum homocysteine level is increased and correlated with endothelin-1 and nitric oxide in Behçet's disease. Br J Ophthalmol 2002; 86: 653-7.

[57] Lee KW, Lip GY, Blann AD. Plasma angiopoietin-1, angiopoietin2 , angiopoietin receptor tie-2, and vascular endothelial growth factor levels in acute coronary syndromes. Circulation 2004; 110 : 2355-60.

[58] Clayton JA, Chalothorn D, Faber JE. Vascular endothelial growth factor-A specifies formation of native collaterals and regulates collateral growth in ischemia. Circ Res 2008; 103: 1027-36.

[59] Cekmen M, Evereklioglu C, Er H, et al. Vascular endothelial growth factor levels are increased and associated with disease activity in patients with Behçet's syndrome. Int J Dermatol 2003; 42: 870-5.

[60] Erdem F, Gündoğdu M, Kiki I, Ali Sari R, Kiziltunç A. Vascular endothelial and basic fibroblast growth factor serum levels in patients with Behçet's disease. Rheumatol Int 2005; 25: 599-603.

[61] Shaker O, Ay El-Deen MA, El Hadidi H, Grace BD, El Sherif H, Abdel Halim A. The role of heat shock protein 60, vascular endothelial growth factor and antiphospholipid antibodies in Behçet disease. Br J Dermatol 2007; 156: 32-7.

[62] Paroli MP, Teodori C, D'Alessandro M, Mariani P, Iannucci G, Paroli M. Increased vascular endothelial growth factor levels in aqueous humor and serum of patients with quiescent uveitis. Eur J Ophthalmol 2007; 17: 938-42.

[63] Yalçin B, Arda N, Tezel GG, Erman M, Alli N. Expressions of vascular endothelial growth factor and CD34 in oral aphthous lesions of Behçet's disease. Anal Quant Cytol Histol 2006; 28: 303-6.

[64] Bozoglu E, Dinc A, Erdem H, Pay S, Simsek I, Kocar IH. Vascular endothelial growth factor and monocyte chemoattractant protein-1 in Behçet's patients with venous thrombosis. Clin Exp Rheumatol 2005; 23 (4 Suppl 38): S42-8.

[65] Salvarani C, Boiardi L, Casali B, et al. Vascular endothelial growth factor gene polymorphisms in Behçet's disease. J Rheumatol 2004; 31: 1785-9.

[66] Nam EJ, Han SW, Kim SU, et al. Association of vascular endothelial growth factor gene polymorphisms with Behçet disease in a Korean population. Hum Immunol 2005; 66: 1068-73.

[67] Akarsu M, Demirkan F, Ozsan GH, et al. Increased levels of tissue factor pathway inhibitor may reflect disease activity and play a role in thrombotic tendency in Behçet's disease. Am J Hematol 2001; 68: $225-30$. 
[68] Zöller B, García de Frutos P, Hillarp A, Dahlbäck B. Thrombophilia as a multigenic disease. Haematologica 1999; 84: 59-70.

[69] Kiraz S, Ertenli I, Oztürk MA, Haznedaroğlu IC, Celik I, Calgüneri M. Pathological haemostasis and "prothrombotic state" in Behçet's disease. Thromb Res 2002; 105: 125-33.

[70] Leiba M, Seligsohn U, Sidi Y, et al. Thrombophilic factors are not the leading cause of thrombosis in Behçet's disease. Ann Rheum Dis 2004; 63: 1445-9.

[71] Ateş A, Düzgün N, Ulu A, Tiryaki AO, Akar N. Factor V gene (1691A and 4070G) and prothrombin gene 20210A mutations in patients with Behçet's disease. Pathophysiol Haemost Thromb 2003; 33: 157-63.

[72] Gurgey A, Balta G, Boyvat A. Factor V Leiden mutation and PAI-1 gene $4 \mathrm{G} / 5 \mathrm{G}$ genotype in thrombotic patients with Behçet's disease. Blood Coagul Fibrinolysis 2003; 14: 121-4.

[73] Espinosa G, Font $\mathrm{J}$, Tàssies $\mathrm{D}$, et al. Vascular involvement in Behçet's disease: relation with thrombophilic factors, coagulation activation, and thrombomodulin. Am J Med 2002; 112: 37-43.

[74] Gül A, Aslantas AB, Tekinay T, Koniçe M, Ozçelik T. Procoagulant mutations and venous thrombosis in Behçet's disease. Rheumatology (Oxford) 1999; 38: 1298-9.

[75] Toydemir PB, Elhan AH, Tükün A, et al. Effects of factor V gene G1691A, methylenetetrahydrofolate reductase gene C677T, and prothrombin gene G20210A mutations on deep venous thrombogenesis in Behçet's disease. J Rheumatol 2000; 27: 2849-54.

[76] Lesprit P, Wechsler B, Piette JC, et al. Activated protein C resistance caused by factor V Arg 506-->Gln mutation has no role in thrombotic manifestations of Behçet's disease. Ann Rheum Dis 1995; 54: 860 .

[77] Silingardi M, Salvarani C, Boiardi L, et al. Factor V Leiden and prothrombin gene G20210A mutations in Italian patients with Behçet's disease and deep vein thrombosis. Arthritis Rheum 2004; 51: 177-83.

[78] Verity DH, Vaughan RW, Madanat W, et al. Factor V Leiden mutation is associated with ocular involvement in Behcet disease. Am J Ophthalmol 1999; 128: 352-6.

[79] Ricart JM, Vayá A, Todolí J, et al. Thrombophilic risk factors and homocysteine levels in Behçet's disease in eastern Spain and their association with thrombotic events. Thromb Haemost 2006; 95: 618-24.

[80] Koster T, Blann AD, Briët E, Vandenbroucke JP, Rosendaal FR. Role of clotting factor VIII in effect of von Willebrand factor on occurrence of deep-vein thrombosis. Lancet 1995; 345: 152-5.

[81] O'Donnell J, Tuddenham EG, Manning R, Kemball-Cook G, Johnson D, Laffan M. High prevalence of elevated factor VIII levels in patients referred for thrombophilia screening: role of increased synthesis and relationship to the acute phase reaction. Thromb Haemost 1997; 77: 825-8

[82] Kraaijenhagen RA, in't Anker PS, Koopman MM, et al. High plasma concentration of factor VIIIc is a major risk factor for venous thromboembolism. Thromb Haemost 2000; 83: 5-9.

[83] Probst K, Fijnheer R, Rothova A. Endothelial cell activation and hypercoagulability in ocular Behçet's disease. Am J Ophthalmol 2004; 137: 850-7.

[84] Navarro S, Ricart JM, Medina P, et al. Activated protein C levels in Behçet's disease and risk of venous thrombosis. $\mathrm{Br} \mathrm{J}$ Haematol 2004; 126: 550-6.

[85] Chauhan AK, Kisucka J, Lamb CB, Bergmeier W, Wagner DD. von Willebrand factor and factor VIII are independently required to form stable occlusive thrombi in injured veins. Blood 2007; 109: 2424-9.

[86] Atalay F, Ernam D, Okten F, Akar N. Elevated FVIII and FIX level in a Behçet's disease patient with intracardiac thrombosis and pulmonary arterial aneurysms. Thromb Res 2005; 115: 159-61.

[87] Scanu AM, Fless GM. Lipoprotein(a): heterogeneity and biological relevance. J Clin Invest 1990; 85: 1705-15.

[88] Scanu AM. Lipoprotein(a): its inheritance and molecular basis of its atherothrombotic role. Mol Cell Biochem 1992; 113: 127-31.

[89] Koschinsky ML, Marcovina SM. Lipoprotein(a): structural implications for pathophysiology. Int J Clin Lab Res 1997; 27: 14-23.

[90] Howard GC, Pizzo SV. Biology of disease. Lipoprotein(a) and its role in atherothrombotic disease. Lab Invest 1994; 64: 373-85.

[91] Gonzalez-Gronow M, Edelberg JM, Pizzo SV. Further characterization of the cellular plasminogen binding site: evidence that plasminogen 2 and lipoprotein a compete for the same site. Biochemistry $1989 ; 28: 2374-7$.
[92] Glueck CJ, Glueck HI, Tracy T, Speirs J, McGray C, Stoop D. Relationship between lipoprotein(a), lipids, apolipoproteins, basal and stimulated fibrinolytic regulators, and D-dimer. Metabolism 1993; 42: 236-46.

[93] Orem A, Değer O, Memiş O, Bahadir S, Ovali E, Cimşit G. Lp(a) lipoprotein levels as a predictor of risk for thrombogenic events in patients with Behçet's disease. Ann Rheum Dis 1995; 54: 726-9.

[94] Gurbuz O, Ozdemir Y, Cosar CB, Kural G. Lipoprotein (a) in Behcet's disease as an indicator of disease activity and in thrombotic complications. Eur J Ophthalmol 2001; 11: 62-5.

[95] Esmat S, El Sherif H, Anwar S, Fahmy I, Elmenyawi M, Shaker O. Lipoprotein (a) and nitrites in Behcet's disease: relationship with disease activity and vascular complications. Eur J Dermatol 2006; 16: 67-71.

[96] Balik O, Gur G, Lenk N, Artuz F, Alli N. Serum lipoprotein (a) levels and Behçet's disease: is there an association? Int J Dermatol 2007; 46: 827-9.

[97] Greaves M. Antiphospholipid antibodies and thrombosis. Lancet 1999; 353: 1348-53.

[98] Sorice M, Pittoni V, Circella A, et al. Anti-prothrombin but not "pure" anti-cardiolipin antibodies are associated with the clinical features of the antiphospholipid antibody syndrome. Thromb Haemost 1998; 80: 713-5.

[99] de Laat B, Eckmann CM, van Schagen M, Meijer AB, Mertens K, van Mourik JA. Correlation between the potency of a beta2glycoprotein I-dependent lupus anticoagulant and the level of resistance to activated protein C. Blood Coagul Fibrinolysis 2008; 19: 757-64.

[100] Pabinger I. Thrombophilia and its impact on pregnancy. Thromb Res 2009; 123 (Suppl 3): S16-21.

[101] Hull RG, Harris EN, Gharavi AE, et al. Anticardiolipin antibodies: occurrence in Behçet's syndrome. Ann Rheum Dis 1984; 43: 7468.

[102] Pereira RM, Gonçalves CR, Bueno C, Meirelles Ede S, Cossermelli W, de Oliveira RM. Anticardiolipin antibodies in Behçet's syndrome: a predictor of a more severe disease. Clin Rheumatol 1989; 8: 289-91.

[103] Zouboulis CC, Büttner P, Tebbe B, Orfanos CE. Anticardiolipin antibodies in Adamantiades-Behçet's disease. Br J Dermatol 1993; 128: 281-4.

[104] al-Dalaan AN, al-Ballaa SR, al-Janadi MA, Bohlega S, Bahabri S. Association of anti-cardiolipin antibodies with vascular thrombosis and neurological manifestation of Behçets disease. Clin Rheumatol 1993; 12: 28-30.

[105] Kang HJ, Lee YW, Han SH, Cho HC, Lee KM. Anticardiolipin and anti-beta2-glycoprotein I antibodies in Behcet's disease. J Korean Med Sci 1998; 13: 400-4.

[106] Tokay S, Direskeneli H, Yurdakul S, Akoglu T. Anticardiolipin antibodies in Behçet's disease: a reassessment. Rheumatology (Oxford) 2001; 40: 192-5.

[107] Aslan H, Pay S, Gok F, et al. Antiannexin V autoantibody in thrombophilic Behçet's disease. Rheumatol Int 2004; 24: 77-9.

[108] Nalçaci M, Pekçelen Y. Antithrombin III, protein C and protein S plasma levels in patients with Behçet's disease. J Int Med Res 1998; 26: 206-8.

[109] Mader R, Ziv M, Adawi M, Mader R, Lavi I. Thrombophilic factors and their relation to thromboembolic and other clinical manifestations in Behçet's disease. J Rheumatol 1999; 26: 24048.

[110] Lenk N, Ozet G, Alli N, Coban O, Erbaşi S. Protein C and protein $\mathrm{S}$ activities in Behçet's disease as risk factors of thrombosis. Int $\mathrm{J}$ Dermatol 1998; 37: 124-5.

[111] Oztürk MA, Ozbalkan Z, Onat AM, et al. Decreased protein Z concentrations complicating the hypercoagulable state of Behçet's disease. Clin Appl Thromb Hemost 2003; 9: 259-63.

[112] Stathakis NE, Economopoulos TC, Papayannis AG, Thomopoulos D. Platelet function, blood coagulation and fibrinolysis in Behcet's syndrome. Blut 1977; 34: 215-22

[113] Ricart JM, Ramón LA, Vayá A, et al. Fibrinolytic inhibitor levels and polymorphisms in Behçet disease and their association with thrombosis. Br J Haematol 2008; 141: 716-9.

[114] Haim S, Brook JG, Gilhar A, et al. Platelet function in Behçet's disease. J Dermatol 1984; 11: 117-20.

[115] Nakano H, Oka H, Matsuda T, et al. Spontaneous platelet aggregation in patients with Behçet's disease by using laser-light scattering aggregometer. Adv Exp Med Biol 2003; 528: 437-41. 
[116] Akar S, Ozcan MA, Ateş H, et al. Circulated activated platelets and increased platelet reactivity in patients with Behçet's disease. Clin Appl Thromb Hemost 2006; 12: 451-7.

[117] Tunc SE, Aksu K, Keser G, et al. Platelet-activating factor and P-selectin activities in thrombotic and nonthrombotic Behçet's patients. Rheumatol Int 2005; 25: 326-31

[118] Martínez M, Ricart JM, Ruiz-Aja S, et al. Platelet activation and red blood cell phosphatidylserine exposure evaluated by flow cytometry in patients with Behçet's disease: are they related to thrombotic events? Pathophysiol Haemost Thromb 2007; 36: 1822.

[119] Polat G, Eskandari G, Kaya TI, et al. Association of the platelet glycoprotein Ia C807T/G873A gene polymorphism and thrombosis in Behçet patients. Haematologia (Budap) 2002; 32: 121-8.
[120] Demiroğlu H, Yalçin S, Büyükaşik Y, Ozcebe OI, Dündar S. Increased erythrocyte aggregation as an indicator for an aggressive clinical course in Behçet's disease: a prospective study. Ann Rheum Dis 1998; 57: 694-6.

[121] Ricart JM, Vaya A, Todolí J, et al. Haemorheological alterations in Behçet's disease are not related to a tendency for venous thrombosis. Thromb Res 2005; 115: 399-404.

[122] Ahn JK, Lee YS, Jeon CH, Koh EM, Cha HS. Treatment of venous thrombosis associated with Behcet's disease: immunosuppressive therapy alone versus immunosuppressive therapy plus anticoagulation. Clin Rheumatol 2008; 27: 201-5.

[123] Sismanoglu M, Omeroglu SN, Mansuroglu D, et al. Coronary artery disease and coronary artery bypass grafting in Behçet's disease. J Card Surg 2005; 20: 160-3.

(C) La Regina et al.; Licensee Bentham Open.

This is an open access article licensed under the terms of the Creative Commons Attribution Non-Commercial License (http://creativecommons.org/licenses/ by-nc/3.0/) which permits unrestricted, non-commercial use, distribution and reproduction in any medium, provided the work is properly cited. 